- estratégico existem passagens intermediárias difíceis de se enquadrar.

O tratamento da adaptação no planejamento está excelente, pois o autor torna claro que o valor do planejamento não está nos planos que produz, mas no processo de produzi-los e menciona o quinto plano francês citado por Eric Trist que, por sua vez, cita Crozier. Devido a essa passagem lingüística, o plano se torna Plano $5^{\mathrm{e}} \mathrm{e}$, numa tradução incompleta do francês, cinquième. Em seguida, continua dizendo que toda a necessidade atual de planejamento provém da falta de administração e controles eficazes, para concluir que o bom (destaque meu) planejamento a longo prazo envolve, entre outras coisas: a) descobrir o inevitável; b) determinar como explorá-lo; e c) receber crédito por tê-lo descoberto.

o capítulo 2 - Objetivos e metas - tem uma seção digna de nota sobre Solução de conflitos entre objetivos e os demais capítulos são:

3. Politicas e alternativas de ação.

4. Planejamento de recursos.

5. Estrutura organizacional.

6. Controle.

7. A organização do trabalho do planejamento.

o capítulo sobre controle começa enfatizando a necessidade de informações relevantes e declara, muito sabiamente, que só é possivel chegar a alguma conclusão sobre a necessidade de determinada informação caso for testado após sua elaboração. O que demonstra o acerto do método simplificatório de $O$ \& $M$, a saber, o teste de uso. Se ninguém usar a informação durante seis meses, ela pode ser eliminada.

Uma pequena nota explica como funciona uma assessoria de planejamento e inúmeros organogramas e fluxogramas completam o livro, que termina citando $\mathrm{A}$ arte da guerra de Sun Tzu, que viveu de 400 a 320 A.C.: "Com muitos cálculos pode-se vencer; com poucos, não se pode. Que chances a menos de vitória tem quem não faz nenhum cálculo."

Tendo assim demonstrado, a contento e historicamente, que meter os peitos pode dar certo mas na maioria das vezes não dá, Ackoff deu um valiosíssimo livro ao empresário.

As referências à prática são, neste caso, norte-americanas, e os casos contados são apropriados, mas infelizmente o tradutor não colocou exemplos nacionais no rodapé. A tradução é muito correta e agradável. O livro tem muito mais conteúdo do que deixam suspeitar as magras 126 páginas. A impressão é muito clara e nitida, apesar do tamanho das letras ser aparentemente Concorde 19155 letras $/ 9 \mathrm{~cm}$. Portanto, a apresentação gráfica e dos desenhos e tabelas acompanha a boa impressão que se recebe deste livro. Em escolas de administração pública e de empresas, em faculdades de engeriharia, em planejamento hospitalar, em todas as áreas enfim, onde o planejamento entra de uma ou outra maneira (quantitativamente ou qualitativamente), recomenda-se 0 livro como leitura. A sabedoria está tão concentrada que é extremamente difícil dar expressão à riqueza de conceitos transmitidos. Se nessa crítica não é possivel citar interminavelmente o autor, inclusive porque os direitos autorais proíbem tal, ao menos tentei dar a pálida impressão do semblante da sabedoria do autor.

Kurt E. Weil

\section{The management of production}

J. D. Radford \& D. B. Richardson, 2. ed. London, New York, MacMillan, St. Martin Press, 1968. VIII + 320 p., 144 il. bibl. $\mathrm{p} /$ cap. Índice remissivo, 36 shillings.

Os autores pertencem ao departamento de engenharia mecânica e de produção do Brighton College of Technology, são engenheiros e têm prática industrial por meio de consultoria em diversas empresas inglesas. O livro foi escrito com a principal finalidade de preparar estudantes para o exame final em administração industrial e igualmente para a análise de sistemas de manufatura. Assim, recomenda-se para estudantes em administração e engenharia. Tem ainda como destino servir de livro de cabeceira para pessoal de controle físico ou financeiro da produção.

O conteúdo do livro acompanha a escola clássica de ensino de administraçăo da produção. Não deve causar dificuldade o uso de uma linguagem técnica inglesa, levemente diferente da norteamericana, pois a terminologia segue o padrão britânico B. S. 3138:1959 do estudo do trabalho. Os 20 capítulos do livro são os seguintes: 
1. O objetivo da administração.

2. Pesquisa, desenvolvimento e projeto.

\section{Localização e construção fabril.}

4. Seleção de equipamento, layout e manutenção.

5. Seleção e planejamento do processo.

6. Manuseio de materiais.

7. Análise de valor e padronização.

8. Estudo do trabalho e ergonomia.

9. Aspectos humanos da administração da produção.

10. Controle de qualidade.

11. Medida do desempenho industrial.

12. Controle da produçãao.

13. Planejamento da produção e peças.

14. Documentos internos e seu uso.

15. Organização e controle de estoques.

16. Carga de máquinas e prioridades.

17. Controle da produção por cartões perfurados.

18. Pesquisa operacional.

19. Análise de redes (PERT).

20. Engenharia de sistemas e PED.

Uma apreciação geral do livro demonstra que ele transmite aproximadamente o dobro das idéias e dos fatos que se esperam de um livro-texto de somente 320 páginas. O "milagre" è conseguido por meio de uma linguagem extremamente sintética, que reduz muitos assuntos a listas de enumeração, por exemplo: “'Tempos predeterminados podem ser variados para cada therblig por: 1 . Complexidade do trabalho. 2. Direção do movimento. 3. Quantidade de uso do corpo. 4. Coordenação mão-vista necessária. 5. Necessidades dos demais sentidos. 6. Posição do therblig no roteiro do movimento. 7 .
Número de therbligs no roteiro e repetição da açăo."

Nessa sintese, o livro lembra, em alguns aspectos (simplificação do trabalho, por exemplo), os velhos cartóes do TWI, tão em voga na década dos 50 . $O$ aluno e o industrial necessitam realmente de um bom professor para tirar o máximo de uma informação resumida, pois falta o exemplo, a explicação de cada linha de informação sintética.

Entretanto, é justamente a informação sintética que melhor prepara para os exames finais e melhor informa o homem que já está na ação diária da fábrica. Assim, o livro atinge plenamente 0 seu objetivo - preparar e servir de manual. Um outro fator que prende a atenção é a ausência de fatos controvertidos, habilmente evitados, como nos problemas de incentivos, escalas salariais e resistência à introdução de novos métodos de trabalho. Assim, nas 320 páginas deste livro se encontram interessantes curvas de desviopadrão comparativas pelo crescimento do tamanho da amostra no controle de qualidade e pelo crescimento do grupoamostra do estudo do tempo de determinado trabalho. No capitulo da medida do desempenho industrial há o detalhado gráfico do ponto de paridade e uma série de gráficos relacionando volume de vendas com lucro ou volume da procura. Até a curva de aprendizado tem a sua fórmula, como também um estudo probabilístico da teoria de quantidade ótima em estoque, acompanhado de exercício prático. Então, globalmente, o livro contém informações além do que se possa esperar.

Criticar um livro como esse é possivel quando se encontram erros técnicos de semântica, ou de conceitos. Tal não acontece. Portanto, vale a pena enumerar alguns pontos que dão satisfação especial - como por exemplo a localização ótima para uma fábrica, o método gráfico de programação linear e todo capitulo sobre o planejamento da produção de peças/componentes. O que é importante e o que é menos essencial num livro condensado é problema muito mais do autor que do crítico - e mais uma vez o ponto de vista dos autores mostrou-se acertado: nada falta no livro e somente poucos assuntos de menos importância foram tratados, como por exemplo o número de lâmpadas de iluminação.

Resumidamente, trata-se de um livro altamente satisfatório, que tem utilidade incrivel para um curso condensado de administração da produção. A escola inglesa de nivel superior, tal como a alemã e francesa, é diferente da norte-americana que, como a brasileira, se baseia em exames parciais e finais, enquanto na Europa o exame é global, de toda área, realizado após aproximadamente dois anos de estudos.

Desse modo, um livro inglês que prepara para um exame, pode ser de estrutura didática diferente da do norte-americano; este se destina a um curso, aquele a um exame, para o qual se devem ler outros livros também. Assim, um livro inglês da escola clássica pode ser mais coerente que o americano, desviando-se algo da restrição semestral, mesmo em menos páginas.

Conseqüentemente, os autores encontraram um sistema de ensino da produção que favorece o estudo autodidata e o uso em escolas superiores. Os livros existentes no Brasil, em português, são todos mais extensos, e contêm maior número de matérias (Buffa, Machline e colaboradores, Starr, Mayer, Maynard, etc.). Mas o que não existe ainda no Brasil é um livro condensado e eficiente como este.

Kurt Ernst Weil 